ARTICLE

\title{
ATP-dependent hydroxylation of an unactivated primary carbon with water
}

Christian Jacoby (10 ${ }^{1}$, Sascha Ferlaino (10 ${ }^{2}$, Dominik Bezold (10 ${ }^{3}$, Henning Jessen (10 ${ }^{3}$, Michael Müller (10 ${ }^{2} \&$ Matthias Boll ${ }^{1 \times}$

Enzymatic hydroxylation of unactivated primary carbons is generally associated with the use of molecular oxygen as co-substrate for monooxygenases. However, in anaerobic cholesterol-degrading bacteria such as Sterolibacterium denitrificans the primary carbon of the isoprenoid side chain is oxidised to a carboxylate in the absence of oxygen. Here, we identify an enzymatic reaction sequence comprising two molybdenum-dependent hydroxylases and one ATP-dependent dehydratase that accomplish the hydroxylation of unactivated primary C26 methyl group of cholesterol with water: (i) hydroxylation of C25 to a tertiary alcohol, (ii) ATP-dependent dehydration to an alkene via a phosphorylated intermediate, (iii) hydroxylation of C26 to an allylic alcohol that is subsequently oxidised to the carboxylate. The three-step enzymatic reaction cascade divides the high activation energy barrier of primary $\mathrm{C}-\mathrm{H}$ bond cleavage into three biologically feasible steps. This finding expands our knowledge of biological $\mathrm{C}-\mathrm{H}$ activations beyond canonical oxygenase-dependent reactions.

\footnotetext{
${ }^{1}$ Microbiology, Faculty of Biology, Albert-Ludwigs-Universität Freiburg, Schänzlestr. 1, 79104 Freiburg, Germany. ${ }^{2}$ Institute of Pharmaceutical Sciences, Albert-Ludwigs-Universität Freiburg, Albertstrasse 25, 79104 Freiburg, Germany. ${ }^{3}$ Institute of Organic Chemistry, Albert-Ludwigs-Universität Freiburg, Albertstrasse 21, 79104 Freiburg, Germany. ${ }^{凶}$ email: matthias.boll@biologie.uni-freiburg.de
} 
T he selective oxidation of unactivated $\mathrm{C}-\mathrm{H}$ bonds at alkyl functionalities to alcohols is of great importance for a plethora of synthetic processes. Enzymatic solutions for these challenging reactions have continuously motivated organic chemists for developing bioinspired strategies ${ }^{1-5}$. Biocatalytic $\mathrm{C}-\mathrm{H}$ bond activations of alkyls via hydroxylation have generally been associated with metal-dependent monooxygenases, peroxidases or peroxygenases ${ }^{6-8}$. As an example, the well-studied cytochrome P450 monooxygenases reduce the dioxygen cosubstrate to the formal oxidation state of a hydroxyl radical, which allows for the hydroxylation of unactivated primary carbons to alcohols 9 . While cytochrome P450 enzymes require an auxiliary electron donor system, peroxygenases and peroxidases depend on a balanced supply with its reactive co-substrate ${ }^{6,8}$.

The use of oxygenases or peroxygenases is not an option for $\mathrm{C}-\mathrm{H}$ bond oxidations in anaerobic hydrocarbon-degrading microorganisms, for which a few oxygen-independent enzymatic solutions for $\mathrm{C}-\mathrm{H}$ bond hydroxylation at activated positions have been discovered in the past decades ${ }^{10}$. Prototypical examples are the water-dependent hydroxylations of the benzylic carbons of $p$-cresol ${ }^{11,12}, p$-cymene ${ }^{13}$, and ethylbenzene $e^{14,15}$, as well as of the allylic carbon of limonene ${ }^{16}$. Here, $\mathrm{C}-\mathrm{H}$ bond activation proceeds via hydride transfer to $\mathrm{FAD}$ or $\mathrm{Mo}(\mathrm{VI})=\mathrm{O}$ cofactors (Fig. 1a-d). In all these reactions the resulting carbocation intermediates are stabilised by the possibility of forming multiple resonance structures. However, the water-dependent hydroxylation of unactivated primary carbons of alkanes or isoprenoids has not been reported so far in enzyme catalysis.

The ubiquitous, biologically active steroids are composed of a tetracyclic steran system and an isoprenoid side chain resulting in a low water-solubility and persistence in the environment. Bacterial degradation of steroids is of global importance for biomass decomposition, removal of environmental pollutants and for intracellular survival of Mycobacterium tuberculosis and other pathogens ${ }^{17-19}$. In aerobic cholesterol degrading bacteria, side chain oxidation is initiated by the hydroxylation of the unactivated primary C26 (or equivalent C27) to a primary alcohol by cytochrome P450 enzymes that is further oxidised to a C26carboxylate $^{20,21}$. The isoprenoid side chain of the latter is then converted to acetyl-CoA and propionyl-CoA units via modified $\beta$-oxidation ${ }^{22,23}$. In denitrifying bacteria, oxygen-independent cholesterol degradation also proceeds via $\beta$-oxidation of the 26 carboxylate intermediate involving highly similar enzymes ${ }^{24-26}$. However, the oxidation of the primary, unactivated C26 to the 26-carboxylate must proceed in an oxygen-independent manner.

In the denitrifying $\beta$-proteobacterial model organism Sterolibacterium denitrificans Chol-1S, anaerobic cholesterol degradation is initiated by the periplasmic isomerization/ dehydrogenation of ring A to cholest-4-en-3-one (CEO) by the AcmA gene product ${ }^{27}$, that may be further $\overline{\text { dehydrogenated to }}$ cholesta-1,4-dien-3-one (CDO) by $\mathrm{AcmB}^{25}$. Both intermediates serve as substrate for steroid $\mathrm{C} 25$ dehydrogenases $(\mathrm{S} 25 \mathrm{DH})$ that hydroxylates tertiary $\mathrm{C} 25$ of the isoprenoid side chain with water to 25-OH-CEO/-CDO in the presence of cytochrome $c$ or an artificial electron acceptor ${ }^{28}$ (Fig. 1e). Periplasmic S25DH belongs to the DMSO reductase family of Mo-cofactor containing enzymes and is composed of the catalytic a-subunit harbouring the Mo-cofactor and the FeS-clusters/heme b containing electron transferring $\beta$ - and $\gamma$-subunits ${ }^{29}$. This enzyme is proposed to abstract a hydride from tertiary $\mathrm{C} 25$ to the $\mathrm{Mo}(\mathrm{VI})=\mathrm{O}$ species yielding the $\mathrm{Mo}(\mathrm{IV})-\mathrm{OH}$ intermediate ${ }^{14}$. The latter transfers the hydroxyl group then back to the assumed tertiary carbocation intermediate; electrons are transferred to cytochrome c. The genome of $S$. denitrificans contains eight homologous genes putatively encoding catalytic a-subunits of S25DH-like enzymes, four of which $\left(\mathrm{S} 25 \mathrm{DH}_{1-4}\right)$ have been heterologously produced together with the corresponding $\beta$ - and $\gamma$-subunits and an essential chaperone. They specifically hydroxylate side chains of

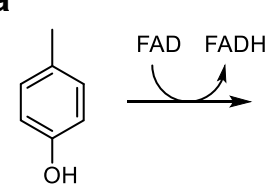

p-cresol
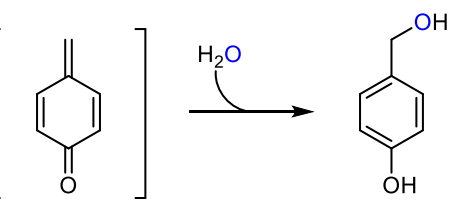

p-Hydroxybenzyl alcohol b

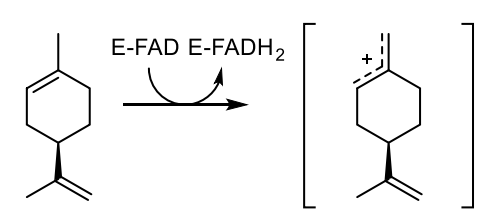

Limonene

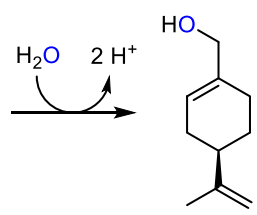

Perillyl alcohol
C<smiles>CCc1ccccc1</smiles>

Ethylbenzene

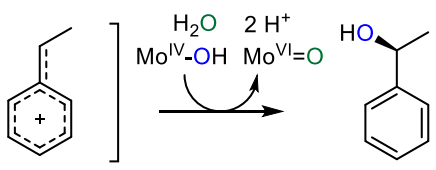

1-Phenylethanol d

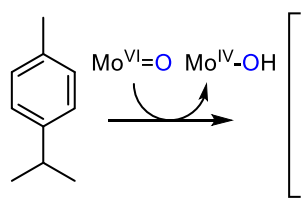

$p$-Cymene
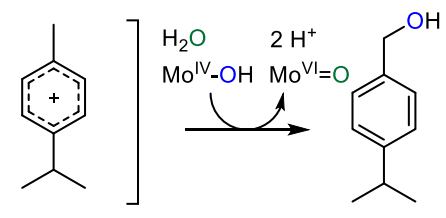

p-Cumic alcohol<smiles>CC(C)CCC[C@@H](C)C1C(C)CCC2C3CC=C4CC(O)CCC4(C)C3CCC21C</smiles>

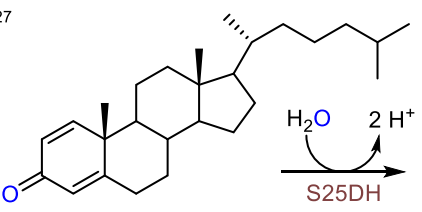

Cholest-1,4-diene-3-one (CDO)

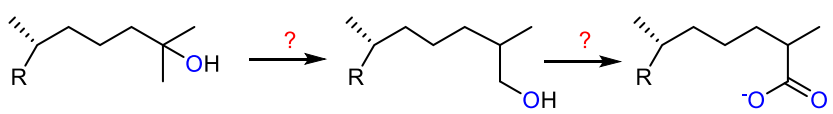

$25-\mathrm{OH}-\mathrm{CDO}$

26-OH-CDO

CDO-26-carboxylate

Fig. 1 Enzymatic water-dependent alkyl hydroxylations. a $p$-Cresol methyl hydroxylase. $\mathbf{b}$ Limonene dehydrogenase. c Ethylbenzene dehydrogenase. $\mathbf{d} p$-Cymene dehydrogenase. e Initial steps of anaerobic cholesterol degradation. The enzyme cascade involved in the proposed conversion of 25-OH-CDO (25-OH-cholesta-1,4-diene-3-one) to CDO-26-carboxylate (cholesta-1,4-diene-3-one-26-carboxylate) via a 26-OH-CDO (26-OH-cholesta-1,4-diene-3one) intermediate was studied in this work. 

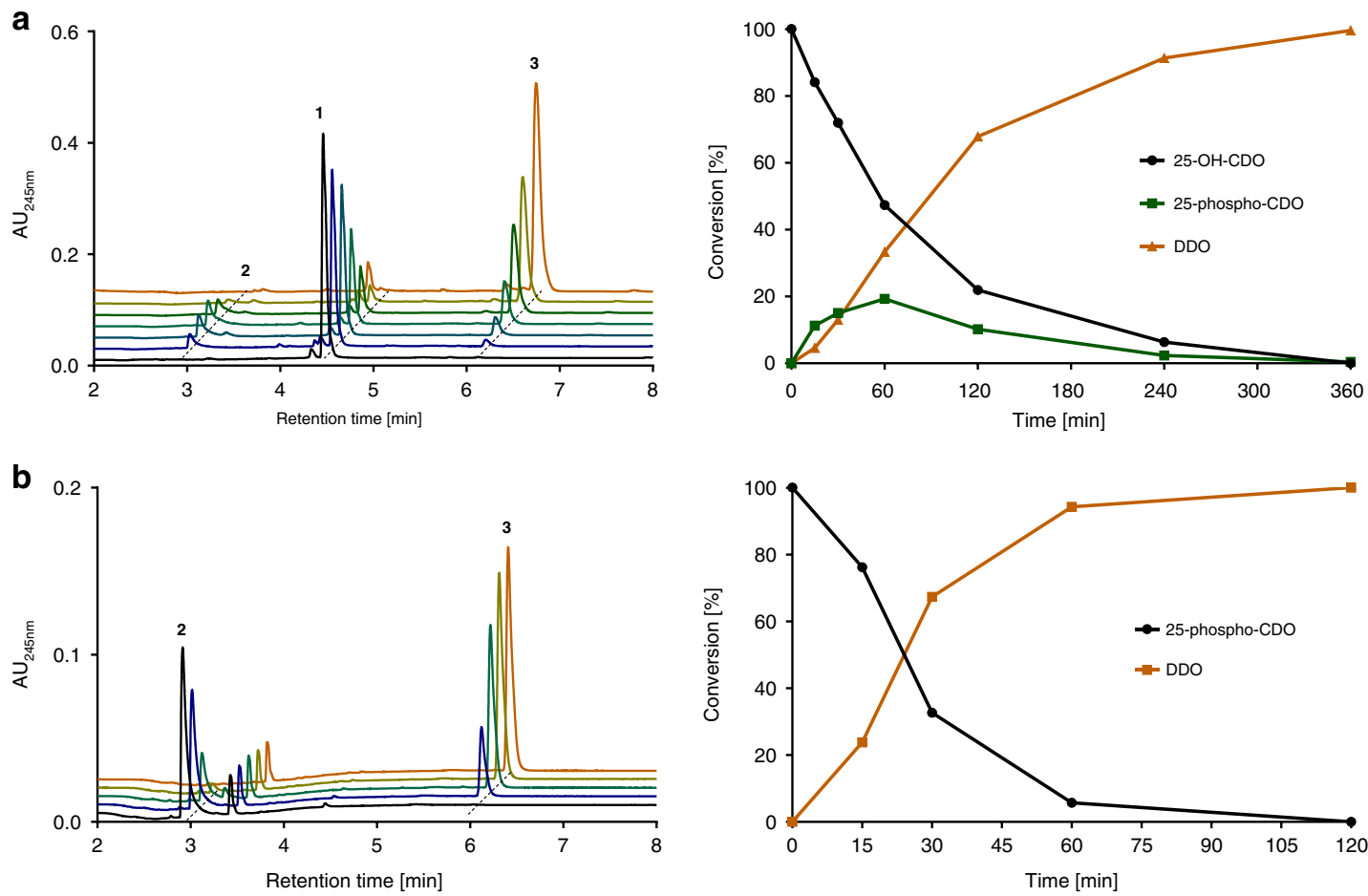

C

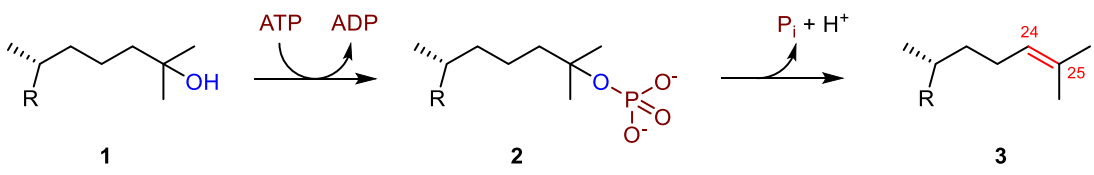

Fig. 2 Oxygen-independent conversion of 25-OH-cholesta-1,4-dien-3-one (1). a Time-, ATP-, and $\mathrm{MgCl}_{2}$-dependent conversion of $0.5 \mathrm{mM} 25-\mathrm{OH}-\mathrm{CDO}$ in soluble cell extracts of $S$. denitrificans. $\mathbf{b}$ ATP-independent conversion of chemically synthesised 25-phospho-CDO. c Proposed reaction sequence of ATP-dependent dehydration of 25-OH-CDO 1 via 25-phospho-CDO $\mathbf{2}$ to desmost-1,4-diene-3-one (DDO, 3). Source data are provided as a Source Data file.

cholesterol and its analogues to tertiary alcohols ${ }^{30,31}$. The rationale for the initial formation of the tertiary alcohol 25-OH-CDO, that cannot be directly further oxidised, during anaerobic cholesterol catabolism has remained enigmatic. Though previous high resolution mass spectrometry (HRMS)-based analyses suggested the primary alcohol $26-\mathrm{OH}-\mathrm{CDO}$ as an intermediate ${ }^{24,32}$, the underlying conversion of a tertiary alcohol to a primary alcohol involves an unknown enzymology.

Here, we aim to identify the enzymatic steps involved in the water-dependent oxidation of a primary carbon atom during anaerobic cholesterol degradation. We demonstrate that the formation of a tertiary alcohol at the cholesterol side chain initiates a three-step enzymatic reaction cascade finally resulting in the oxidation of unactivated C26 to a carboxylate.

\section{Results}

Enzymatic dehydration of 25-OH-cholesta-1,4-diene-3-one. To elucidate the enzymology responsible for production of CDO-26oate, we synthesised 25-OH-CDO from CEO using overproduced $\mathrm{S} 25 \mathrm{DH}$ and AcmB. Cell-free extracts of S. denitrificans grown with cholesterol under denitrifying condition were anoxically reacted with $25-\mathrm{OH}-\mathrm{CDO}$ in the presence of a multitude of natural and artificial electron acceptors (e.g., $\mathrm{NAD}[\mathrm{P}]^{+}, \mathrm{K}_{3}[\mathrm{Fe}$ $(\mathrm{CN})_{6}$, or 2,6-dichlorophenolindophenol at $0.5 \mathrm{mM}$, respectively). In no case, conversion of $25-\mathrm{OH}-\mathrm{CDO}$ to a product was observed.
In further trials, electron acceptors were omitted in the reaction assays and a number of potential co-substrates were tested. In the presence of ATP and $\mathrm{MgCl}_{2}$ (5 $\mathrm{mM}$ each), the time-dependent conversion of 25-OH-CDO 1 to a minor, more polar intermediate 2 was observed using ultra-fast performance liquid chromatography (UPLC) analyses, which was readily further converted to a second less polar product 3, (Fig. 2). After ultracentrifugation of cell-free extracts this conversion was found to occur only in the soluble protein fraction. UPLC- HRMS analysis of $\mathbf{2}$ did not allow a clear assignment to a molecular mass, whereas analysis of compound 3 revealed a $[\mathrm{M}+\mathrm{H}]^{+}$ion with $\mathrm{m} / z=381.3161 \pm 0.4$ Da suggesting the loss of $\mathrm{H}_{2} \mathrm{O}$ from the substrate $(\mathrm{m} / z=$ $399.3274 \pm 1.1$; for MS data of all steroid intermediates analysed in this work, see Supplementary Table 1). The product 3 was purified by preparative HPLC and identified by ${ }^{1} \mathrm{H},{ }^{13} \mathrm{C}$, and $2 \mathrm{D}$ NMR analyses as desmost-1,4-diene-3-one (DDO) containing an allylic $\Delta 24$ double $\bar{e}$ bond (Supplementary Figs. 1-3). Thus, the hydroxyl functionality introduced by $\mathrm{S} 25 \mathrm{DH}$ was subsequently eliminated to an alkene by an ATP-dependent 25-OH-CDO dehydration activity.

We tested whether product 2 represents a phosphorylated intermediate during the ATP-dependent dehydration of 25-OHCDO. For this purpose we chemically synthesised a 25-phosphoCDO standard from enzymatically prepared 25-OH-CDO. We opted for a $\mathrm{P}(\mathrm{III})$-amidite approach due to the steric hindrance of the tertiary $\mathrm{OH}$, using a bis fluorenylmethyl (Fm) protected 

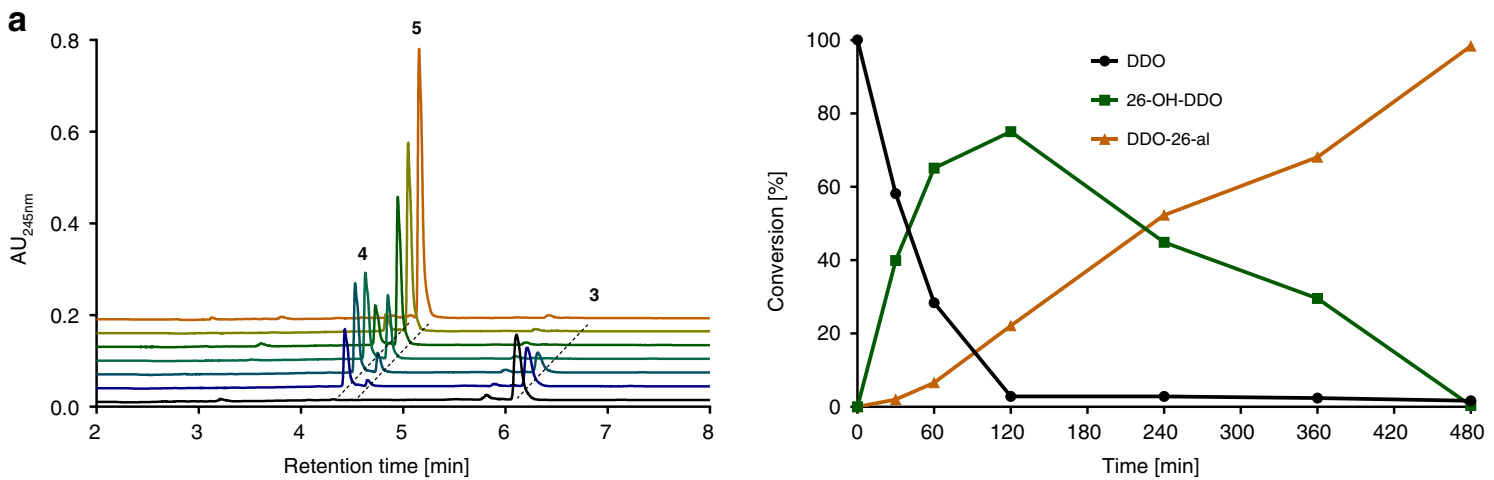

b

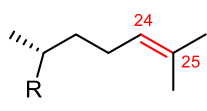

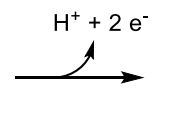

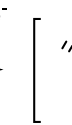$$
\text { All }
$$
Allylic cation
intermediate

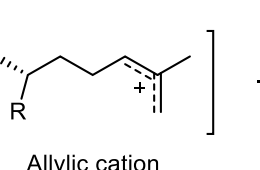

(3)

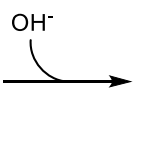<smiles>[R]C(C)CCC=C(C)CO</smiles>

4

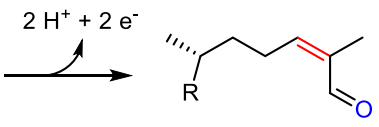

5

Fig. 3 Oxygen-independent conversion of desmost-1,4-dien-3-one (3). a Conversion of DDO to the two products 4 and 5 in soluble extracts of S. denitrificans. b Reactions sequence obtained via a proposed allylic cation intermediate after NMR-based identification of products as $26-\mathrm{OH}-\mathrm{DDO}$ 4 and the corresponding C26-aldehyde DDO-26-al 5. The enzyme involved was identified as a Mo-dependent hydroxylase. Source data are provided as a Source Data file.

P-amidite ${ }^{33}$ that indeed facilitated the reaction. After oxidation and removal of the Fm groups with 1,8-diazabicyclo[5.4.0] undec7 -en (DBU), the product was obtained in a one-flask operation without elimination of the labile phosphate in 39\% yield after purification (for MS and NMR analyses, see Supplementary Figs. 4 and 5). When 25-phospho-CDO (2) was incubated with soluble $S$. denitrificans extracts, the ATP-independent conversion into DDO (3) was observed (Fig. 2b). The kinetic parameters of 25-OH- and 25-phospho-CDO conversions were $V_{\max }=11.7 \pm$ $0.6 \mathrm{nmol} \mathrm{min}{ }^{-1} \mathrm{mg}^{-1} / K_{\mathrm{m}}=41 \pm 8 \mu \mathrm{M}$ for 25-OH-CDO, and $V_{\max }=23.2 \pm 1 \mathrm{nmol} \mathrm{min}^{-1} \mathrm{mg}^{-1} / K_{\mathrm{m}}=227 \pm 32 \mu \mathrm{M}$ for $25-$ phospho-CDO (mean values \pm standard deviations of enzyme activity measurements at various substrate concentrations, for the data points used see Supplementary Fig. 6a, b). In summary, the results indicate that kinase and phosphate elimination partial activities are involved in the conversion of $25-\mathrm{OH}-\mathrm{CDO}(\mathbf{1})$ to DDO (3) via 25-phospho-CDO (2) (Fig. 2c).

For the determination of cofactor specificity and stoichiometry, the ATP-dependent 25-OH-CDO dehydration activity was enriched via ammonium sulphate precipitation (activity retained in the suspended $50 \%$ saturation pellet). During formation of DDO from 25-OH-CDO no other nucleoside triphosphate than ATP was accepted as co-substrate; $\mathrm{Mg}^{2+}$ could substitute for $\mathrm{Mn}^{2+}$ albeit at only $5 \%$ activity. UPLC analyses of adenosine nucleotides revealed that $1.2 \pm 0.1 \mathrm{~mol}$ ATP were hydrolysed to $0.9 \pm 0.1 \mathrm{~mol} \mathrm{ADP}$ and $0.3 \pm 0.1 \mathrm{~mol}$ AMP per mol 25-OH-CDO consumed (mean value \pm standard deviation in three independent determinations); ATP hydrolysis was negligible in the absence of the steroid.

Oxidation of the allylic methyl group. For analysing the further conversion of DDO, we enzymatically synthesised DDO from 25$\mathrm{OH}-\mathrm{CDO}$ using cell-free extracts from $S$. denitrificans. Strictly depending on $\mathrm{K}_{3}\left[\mathrm{Fe}(\mathrm{CN})_{6}\right]$ as electron acceptor, cell-free extracts of $S$. denitrificans converted DDO to product 4 that was subsequently converted to $\mathbf{5}$ in assays performed anaerobically (Fig. 3).
Compounds 4 and 5 were analysed by UPLC-HRMS and ${ }^{1} \mathrm{H}$, ${ }^{13} \mathrm{C}$, and $2 \mathrm{D}$ NMR spectroscopy. The products were identified as 26-OH-DDO 4, and the corresponding aldehyde DDO-26-al 5 (Supplementary Figs. 7-12). Notably, NOE NMR analyses clearly showed that the hydroxyl functionality was stereoselectively introduced in the cis position relative to the $\mathrm{C} 24$ proton giving the $(E)-\mathrm{C} 26-\mathrm{OH}-\mathrm{DDO}$ and not the $(Z)$-isomer.

In summary, DDO 3 formed by ATP-dependent dehydration of the tertiary alcohol was hydroxylated first to the allylic primary alcohol 4 with water, followed by the oxidation to the aldehyde 5 . Specific activities in cell-free extracts were $2 \pm 0.1 \mathrm{nmol} \mathrm{min}^{-1} \mathrm{mg}^{-1}$ for 26-OH-DDO formation and $1.2 \pm 0.2 \mathrm{nmol} \mathrm{min}{ }^{-1} \mathrm{mg}^{-1}$ for 26-OH-DDO dehydrogenation (mean value \pm standard deviation in three biological replicates of cell extract preparation).

Heterologous production of desmost-1,4-dien-3-one (DDO) hydroxylase. In addition to the previously investigated $\mathrm{S} 25 \mathrm{DH}_{1-4}$ isoenzymes, the genome of $S$. denitrificans contains four gene clusters encoding the putative $\alpha \beta \gamma$-subunits of related Modependent dehydrogenases $\left(\mathrm{DH}_{5-8}\right)^{29,30}$. Among these, the $\alpha$ subunits $\mathrm{DH}_{5-7}$ form a phylogenetic subcluster with amino acid sequence identities $>80 \%$; that of $\mathrm{DH}_{8}$ is rather distantly related (Fig. 4a).

To test whether one of the $\mathrm{DH}_{5-7}$ enzymes may be involved in the water-dependent hydroxylation of DDO, we heterologously expressed the genes potentially encoding the active site $\alpha \beta \gamma$ subunits of $\mathrm{DH}_{5-7}$ and an assumed $\delta$-chaperone in the $\beta$ proteobacterium Thauera aromatica as described for $\mathrm{S}_{2} 5 \mathrm{DH}_{1-4}{ }^{30}$. Using cell-free extracts from $T$. aromatica producing $\mathrm{DH}_{5-7}$, only with $\mathrm{DH}_{5}$ we observed the $\mathrm{K}_{3}\left[\mathrm{Fe}(\mathrm{CN})_{6}\right]$ dependent conversion of DDO to 26-OH-DDO; we therefore refer this enzyme to $\mathrm{S} 26 \mathrm{DH}_{1}$. Heterologously produced $\mathrm{S}_{2} 6 \mathrm{DH}_{1}$ was enriched from $T$. aromatica extracts by three chromatographic steps under anaerobic conditions using a modified protocol established for $\mathrm{S}_{2} 5 \mathrm{DH}_{1-4}{ }^{30}$.

SDS-PAGE analysis of enriched $\mathrm{S}_{2} 6 \mathrm{DH}_{1}$ revealed four major protein bands (Fig. 4b) that were excised, tryptically digested, and analysed by electrospray ionisation quadrupole time-of-flight 

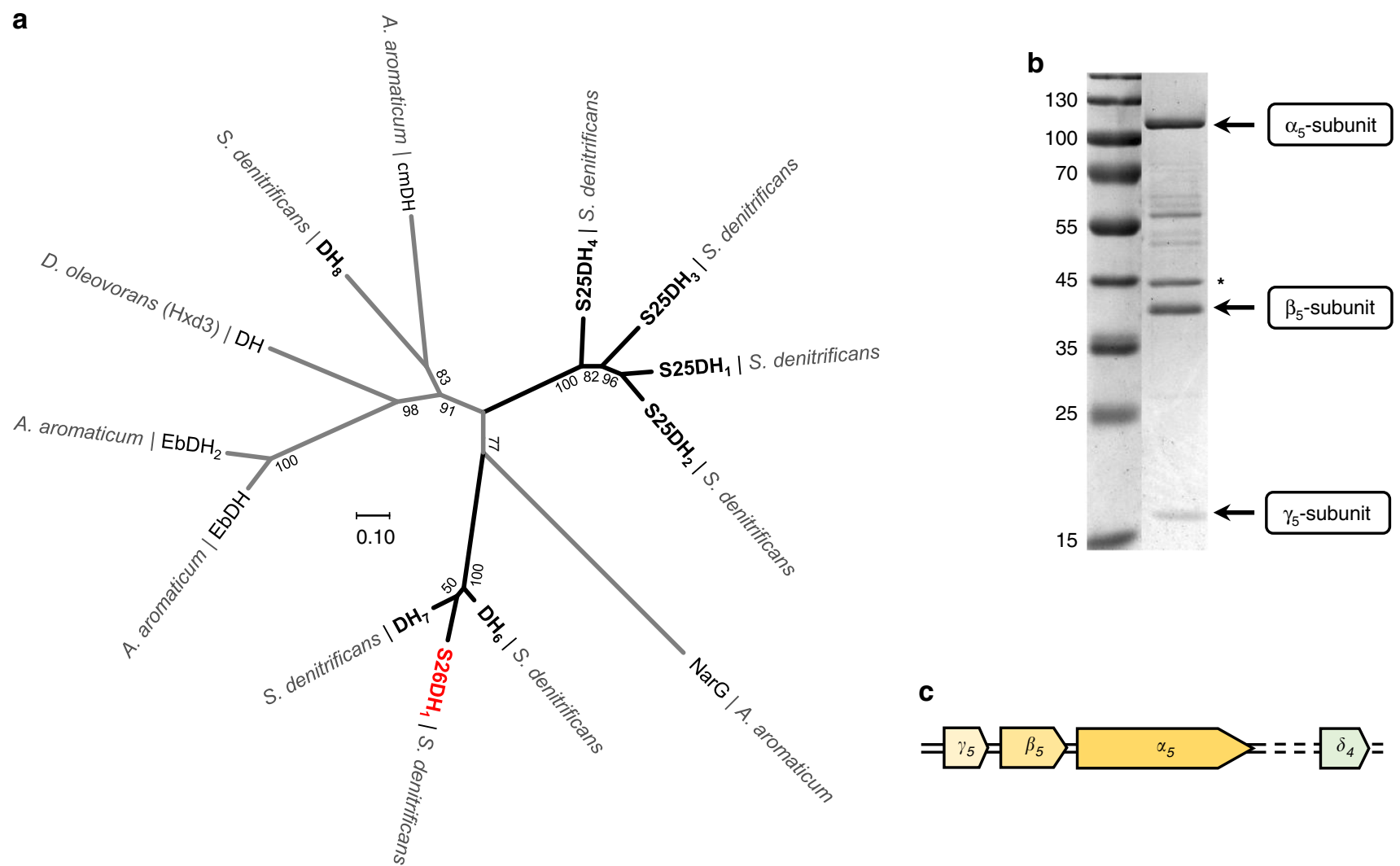

Fig. 4 Phylogeny and enrichment of recombinant S26DH from S. denitrificans. a Phylogenetic tree of S25DH-like Mo-enzymes of the DMSO reductase family. A. = Aromatoleum; $D .=$ Desulfococcus; $\alpha$-subunits of $\mathrm{CmDH}=p$-cymene dehydrogenase; $\mathrm{EbDH}=$ ethylbenzene dehydrogenase; NarG $=$ nitrate reductase. The previously assigned $\mathrm{DH}_{5}$ is now referred to as $\mathrm{S}_{2} 6 \mathrm{DH}_{1}$ (marked in red). b SDS-PAGE of S26DH heterologously produced in $T$. aromatica; the numbers refer to the molecular masses $(\mathrm{kDa})$ of a standard. The band marked with an asterisk was identified as co-purified 6-oxocyclohex-1-ene-1carboxyl-CoA hydrolase from T. aromatica; the minor band eluting slightly above the $55 \mathrm{kDa}$ is a degradation product of the $\alpha_{5}$-subunit (Supplementary Table 2). c Cluster of genes encoding the $\alpha \beta \gamma$-subunits and the gene encoding the $\delta$-chaperone of $\mathrm{S} 6 \mathrm{DH}_{1}$ (accession numbers: $\gamma \beta \alpha$-subunits, WP_154715926-8; $\delta$-chaperone, WP_154716737). Source data are provided as a Source Data file.

mass spectrometry (ESI-Q-TOF-MS). The masses of the ions obtained from tryptic peptides confirmed the presence of the $\alpha, \beta$, $\gamma$-subunits of $\mathrm{S}_{2} 6 \mathrm{DH}_{1}$ from $S$. denitrificans, those obtained from the band eluting at $43 \mathrm{kDa}$ were assigned to a co-purified 6oxocyclohex-1-ene-1-carboxyl-CoA hydrolase from T. aromatica (Supplementary Table 2). The latter cofactor-free enzyme plays a role in the catabolic benzoyl-CoA degradation pathway ${ }^{34}$ and is unlikely to be associated with steroid hydroxylation.

Amino acid sequence similarities of $\mathrm{S} 26 \mathrm{DH}_{1}$ with characterised $\mathrm{S} 25 \mathrm{DHs}^{30}$ suggested the presence of one Mo-cofactor, four [4Fe$4 \mathrm{~S}]$ clusters, one [3Fe-4S] cluster, and a heme $b$. The metal content of $\mathrm{S}_{2} 6 \mathrm{DH}_{1}$ determined by colorimetric procedures was $0.81 \pm 0.03 \mathrm{~mol} \mathrm{Mo}, 19.7 \pm 0.4 \mathrm{~mol} \mathrm{Fe}$, and $0.89 \pm 0.01 \mathrm{~mol} \mathrm{heme} b$ per mol S26DH $\mathrm{DH}_{1}$, respectively (mean value \pm standard deviation in three different enzyme preparations). These values are in good agreement with the expected cofactor content and with the values determined for other $\mathrm{S} 25 \mathrm{DHs}{ }^{30}$.

Unexpectedly, enriched $\mathrm{S}_{2} 6 \mathrm{DH}_{1}$ catalysed the hydroxylation of DDO to 26-OH-DDO 4 and the subsequent dehydrogenation of the latter to DDO-26-al 5 with $\mathrm{K}_{3}\left[\mathrm{Fe}(\mathrm{CN})_{6}\right]$ as electron acceptor (Supplementary Fig. 13). As a control, T. aromatica extracts containing the plasmid without the $\mathrm{S}_{2} 6 \mathrm{DH}_{1}$ genes did not catalyse such a reaction. Both partial reactions of $\mathrm{S}_{2} 6 \mathrm{DH}_{1}$ dehydrogenase followed Michaelis-Menten kinetics with $V_{\max }=$ $219 \pm 11 \mathrm{nmol} \mathrm{min}^{-1} \mathrm{mg}^{-1} / K_{\mathrm{m}}=123 \pm 25 \mu \mathrm{M}$ for DDO hydroxylation, and $V_{\max }=73 \pm 3 \mathrm{nmol} \mathrm{min} \mathrm{mg}^{-1} / K_{\mathrm{m}}=83 \pm 12 \mu \mathrm{M}$ for 26 $\mathrm{OH}-\mathrm{DDO}$ dehydrogenation (mean values \pm standard deviations of enzyme activity measurements at various substrate concentrations, for the data points used see Supplementary Fig. 6c, d). No further oxidation to a carboxylate was observed by enriched $\mathrm{S}_{2} 6 \mathrm{DH}_{1}$.

Oxidation of 26-OH-DDO to DDO-26-carboxylate. Enriched $\mathrm{S}_{2} 6 \mathrm{DH}_{1}$ used $\mathrm{K}_{3}\left[\mathrm{Fe}(\mathrm{CN})_{6}\right]$ but not $\mathrm{NAD}^{+}$as electron acceptor for the oxidation of the allylic alcohol 4 to the aldehyde 5, which is in agreement with its proposed periplasmic location (see Discussion). We tested whether this activity is relevant for the cholesterol catabolic pathway or whether an additional cytoplasmic alcohol dehydrogenase is involved. Using $\mathrm{NAD}^{+}$as electron acceptor, extracts from $S$. denitrificans grown with cholesterol showed virtually no conversion of 26-OH-DDO 4 to DDO-26-al

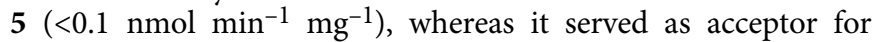
the ready oxidation of DDO-26-al 5 to DDO-26-carboxylate (5 \pm $0.2 \mathrm{nmol} \mathrm{min}{ }^{-1} \mathrm{mg}^{-1}$ ) (mean value \pm standard deviation in three replicates). In this assay, formation of an additional product was observed that after ESI-Q-TOF-MS analyses was assigned to 26OH-DDO (Supplementary Table 1, Fig. 14). Obviously, the $\mathrm{NADH}$ formed during DDO-26-al oxidation served as donor for a promiscuous dehydrogenase that reduced the $\mathrm{C} 26$ aldehyde to the C26 alcohol.

Recently, a cholesterol induced gene was identified in $S$. denitrificans (WP_154716401) that was hypothesised to encode an aldehyde dehydrogenase (C26-ALDH) involved in cholesterol C26 oxidation ${ }^{25}$. We heterologously expressed this gene in E. coli, and extracts from cells producing the recombinant enzyme 
indeed catalysed the conversion of DDO-26-al to DDO-26carboxylate (Supplementary Fig. 15a); in control experiments no such conversions were observed in E. coli wild-type without the plasmid expressing WP_154716401. In the presence of MgATP and CoA, the DDO-26-carboxylate formed was further converted to DDO-26-CoA by the previously characterised AMP-forming C26-carboxylate CoA ligase activity ${ }^{25}$, thereby initiating $\beta$ oxidation of the isoprenoid side chain (Supplementary Fig. 15b).

\section{Discussion}

In this work we identified an enzymatic reaction sequence that allows for the oxidation of an unactivated primary carbon to a carboxylate using water as only hydroxylating agent. In this enzyme cascade the high activation energy barrier for $\mathrm{C}-\mathrm{H}$ bond hydroxylation of a primary carbon is divided into three individual steps, each of which being energetically and mechanistically plausible under cellular conditions. The $\mathrm{C}-\mathrm{H}$ bond dissociation energies to carbocations and hydrides relevant for the hydroxylation of tertiary C25 in cholesterol and allylic C26 in desmosterol are $142 \mathrm{~kJ} \mathrm{~mol}^{-1}$ and $117 \mathrm{~kJ} \mathrm{~mol}^{-1}$ lower than that for the primary C26 of cholesterol, respectively (based on gas phase calculations for the isopentane and 2-methyl-2-butene analogues) ${ }^{35}$. Thus, the rationale for the initial formation of a tertiary alcohol during anaerobic cholesterol catabolism ${ }^{28,29}$ is to enable the ATPdependent dehydration to a trisubstituted alkene that is crucial for the subsequent water-dependent hydroxylation of the allylic carbon via a relatively stable allylic carbocation intermediate. The major challenge of oxygen-independent primary carbon activation represents the dehydration of the tertiary alcohol that is achieved by coupling to exergonic ATP hydrolysis $\left(\Delta \mathrm{G}^{\prime} \approx-50 \mathrm{~kJ} \mathrm{~mol}^{-1}\right)$. The phosphate eliminated from the phosphoester intermediate is a much better leaving group than water. A related reaction is known from isoprenoid biosynthesis via the mevalonate pathway: $(R)$-mevalonate-5-diphosphate is ATPdependently decarboxylated to isopentenyl diphosphate ${ }^{36,37}$. Here, phosphate elimination from an assumed phosphorylated intermediate is accompanied by decarboxylation, which additionally drives the elimination reaction forward (Supplementary Fig. 16). ATP-dependent dehydration has also been reported for the recycling of spontaneously formed $\mathrm{NAD}(\mathrm{P}) \mathrm{H}$ hydrates ${ }^{38}$, however it is unclear whether it proceeds via a phosphorylated intermediate.

While a reaction mechanism via tertiary and allylic carbocation intermediates is plausible for the two Mo-dependent hydroxylases $\mathrm{S} 25 \mathrm{DH}_{1} / \mathrm{S}_{2} 6 \mathrm{DH}_{1}$, it remains uncertain whether this is the case for phosphate elimination from 25-phospho-DDO. If the phosphate elimination would proceed via the identical tertiary carbocation as proposed for S25DH catalysis, the question rises why it is not directly deprotonated by $\mathrm{S} 25 \mathrm{DH}$ to the alkene in a single step? Probably, the rebound of the hydroxyl-functionality at the assumed $\mathrm{Mo}(\mathrm{IV})-\mathrm{OH}$ intermediate to the carbocation is much faster than a competing deprotonation at $\mathrm{C} 24$ to an alkene by a putative base.

The reaction cascade identified in this work allows in principle for any enzymatic water-dependent hydroxylation at a primary carbon next to a tertiary one. The genome of $S$. denitrificans contains two further copies of S26DH-like enzymes and they may represent isoenzymes specifically involved in the hydroxylation of allylic methyl groups of intermediates during catabolism of steroids with modified isoprenoid side chains such as $\beta$-sitosterol or ergosterol. Hence, a pair of specific Mo-dependent S25DH and S26DH appears to be required for the hydroxylation of primary carbons at the individual isoprenoid chains. The reaction cascade may also be involved in the degradation of non-steroidal isoprenoids or tertiary alcohols. E.g., the anaerobic degradation of the fuel oxygenate methyl tert-butyl ether, an environmental pollutant of global concern, has frequently been described at anoxic environments ${ }^{39,40}$. However, the anoxic degradation of the tert-butanol intermediate is unknown but could in principle be accomplished via ATP-dependent dehydration to isobutene, analogous to the described pathway.

Cholesterol degradation in anaerobic bacteria is initiated in the periplasm by $\mathrm{AcmA}, \mathrm{S} 25 \mathrm{DH}_{1}$, and probably $\mathrm{AcmB}$ dependent conversion into $25-\mathrm{OH}-\mathrm{CDO} / 25-\mathrm{OH}-\mathrm{DDO}$ (oxidation to the diene in ring A may also occur later in the pathway). However, subsequent alkene formation is ATP-dependent and therefore has to occur in the cytoplasm. In contrast, subsequent C26 hydroxylation and oxidation to the $\mathrm{C} 26$ aldehyde will again take place in the periplasm as evidenced by the N-terminal twin-arginine translocation (TAT) sequence present in S25DH and S26DH (Supplementary Table S3). Thus, initial steps of anaerobic cholesterol degradation involve enzymes alternately accessing their substrates from the periplasm and the cytoplasm (Fig. 5). Though flip-flop of cholesterol between the two leaflets of biological membranes is generally considered fast with rate constants in the $10^{4} \mathrm{~s}^{-1}$ range ${ }^{41-43}$, it is 5.5 -fold faster for $25-\mathrm{OH}$-cholesterol vs cholesterol $^{43}$. Thus, initial side chain-hydroxylation facilitates the accessibility of cholesterol-derived intermediates from both sides of the cytoplasmic membrane, which appears to be crucial for the reaction cascade involved in water-dependent primary carbon oxidation.

\section{Methods}

Chemicals and bacterial strains. The chemicals used were of analytic grade. Sterolibacterium denitrificans Chol-1S (DSMZ 13999) and Thauera aromatica K172 (DSMZ 6984) were obtained from the Deutsche Sammlung für Mikroorganismen und Zellkulturen (DSMZ, Braunschweig, Germany). E. coli BL21 (DE3) and E. coli 5 a were obtained from New England Biolabs (Frankfurt, Germany).

Synthesis of non-phosphorylated steroidal compounds. 25-Hydroxy-cholesta1,4-diene-3-one (25-OH-CDO) was enzymatically synthesised from the commercially available cholest-4-en-3-one (CDO) using $\mathrm{AcmB}$ and $\mathrm{S} 25 \mathrm{DH}_{1}$ from $S$. denitrificans after heterologous production in E. coli BL21 (DE3) and T. aromatica K172, respectively ${ }^{30}$. The enzyme assays contained 1-2 mM CDO, $50 \mathrm{mM}$ Tris/ $\mathrm{HCl}$ buffer ( $\mathrm{pH} 7.5$ ), 6\% (w/v) 2-hydroxypropyl- $\beta$-cyclodextrin (HPCD), $5 \mathrm{mM}$ $\mathrm{K}_{3}\left[\mathrm{Fe}(\mathrm{CN})_{6}\right], 2 \%(\mathrm{v} / \mathrm{v})$ volume cell-free extracts from $E$. coli BL21 producing $\mathrm{AcmB}$, and $4 \%(\mathrm{v} / \mathrm{v})$ volume cell-free extracts from $T$. aromatica K172 producing S25DH. For synthesis of desmost-1,4-diene-3-one (DDO), soluble proteins from Sterolibacterium denitrificans ( $S$. denitrificans) were used anaerobically as follows: 1-2 mM 25-OH-CDO, 50 mM Tris/HCl buffer (pH 7.8), 6\% (w/v) HPCD, 5 mM ATP, $5 \mathrm{mM} \mathrm{MgCl}_{2}$, and $5 \%(\mathrm{v} / \mathrm{v}$ ) volume extracts (cell free) of $S$. denitrificans. 26-OH-DDO and desmost-1,4-diene-3-one-26-al (DDO-26-al) were produced as followed: 1-2 mM DDO, $50 \mathrm{mM}$ Tris/HCl (pH 7.0), 6\% (w/v) HPCD, $5 \mathrm{mM} \mathrm{K}_{3}[\mathrm{Fe}$ $\left.(\mathrm{CN})_{6}\right]$, and $5 \%(\mathrm{v} / \mathrm{v})$ volume cell-free extracts of $S$. denitrificans. The enzymatic assays were performed on the $100-1000 \mathrm{~mL}$ scale at $30^{\circ} \mathrm{C}$ for at least 16 hours. Products were extracted in 2 volumes ethyl acetate, evaporated, and purified by preparative HPLC. For columns and solvents used, see the description of enzyme assays with individual steroids. Samples were lyophilised and solved in 2-propanol before use.

Synthesis of 25-phospho-cholesta-1,4-diene-3-one. Bis( $(9 H$-fluoren-9-yl) methyl) diisopropylphosphoramidite $(90 \%, 29.0 \mathrm{mg}, 50.0 \mu \mathrm{mol}, 2.0$ eq.) was coevaporated with dry acetonitrile $(2 \mathrm{~mL})$ and dissolved in dry $N, N$-dimethylformamide $(1 \mathrm{~mL}) .25-\mathrm{OH}-\mathrm{CDO}(10 \mathrm{mg}, 25 \mu \mathrm{mol}, 1 \mathrm{eq}$.) and 4,5-dicyanoimidazole $(5.9 \mathrm{mg}, 50 \mu \mathrm{mol}, 2$ eq.) were added and the solution was stirred for $30 \mathrm{~min}$. The solution was cooled to $0{ }^{\circ} \mathrm{C}$ and meta-chloroperoxybenzoic acid $(77 \%, 6.7 \mathrm{mg}$, $50 \mu \mathrm{mol}, 2$ eq.) was added. After stirring for $15 \mathrm{~min}, 1,8$-diazabicyclo[5.4.0] undec7-ene $(20 \mu \mathrm{L}, 125 \mu \mathrm{mol}, 5 \mathrm{eq}$.) was added and the mixture was stirred for another $15 \mathrm{~min}$. Subsequently, the solvent was removed under reduced pressure and the crude mixture was purified by preparative HPLC (Solvent A: $10 \mathrm{mM} \mathrm{NH}_{4} \mathrm{OAc}$ in water; Solvent B: $10 \mathrm{mM} \mathrm{NH}_{4} \mathrm{OAc}$ in methanol. 0-3 min isocratic $100 \% \mathrm{~A}, 3-9 \mathrm{~min}$ gradient to $100 \% \mathrm{~B}, 9-35 \mathrm{~min}$ isocratic $100 \% \mathrm{~B}$ ) to obtain the desired phosphate ammonium salt $(5 \mathrm{mg}, 9.74 \mu \mathrm{mol}, 39 \%)$ as a colourless solid. The product was analysed by ${ }^{1} \mathrm{H},{ }^{13} \mathrm{C},{ }^{31} \mathrm{P}\left\{{ }^{1} \mathrm{H}\right\} \mathrm{NMR}$, and ESI-HRMS. The spectra are shown in the Supplementary Figs. S2 and S3. ${ }^{1} \mathrm{H}$ NMR $\left(400 \mathrm{MHz}\right.$, methanol- $\left.d_{4}\right): \delta=7.32(\mathrm{~d}, J=$ $10.1 \mathrm{~Hz}, 1 \mathrm{H}), 6.23(\mathrm{dd}, J=10.1,2.0 \mathrm{~Hz}, 1 \mathrm{H}), 6.08(\mathrm{t}, J=1.7 \mathrm{~Hz}, 1 \mathrm{H}), 2.64-2.55$ $(\mathrm{m}, 1 \mathrm{H}), 2.45-2.38(\mathrm{~m}, 1 \mathrm{H}), 2.11(\mathrm{dt}, J=13.1,3.7 \mathrm{~Hz}, 1 \mathrm{H}), 2.07-1.99(\mathrm{~m}, 1 \mathrm{H})$, $1.95-1.85(\mathrm{~m}, 1 \mathrm{H}), 1.82-1.70(\mathrm{~m}, 4 \mathrm{H}), 1.66-1.50(\mathrm{~m}, 4 \mathrm{H}), 1.43(\mathrm{~s}, 6 \mathrm{H})$, 


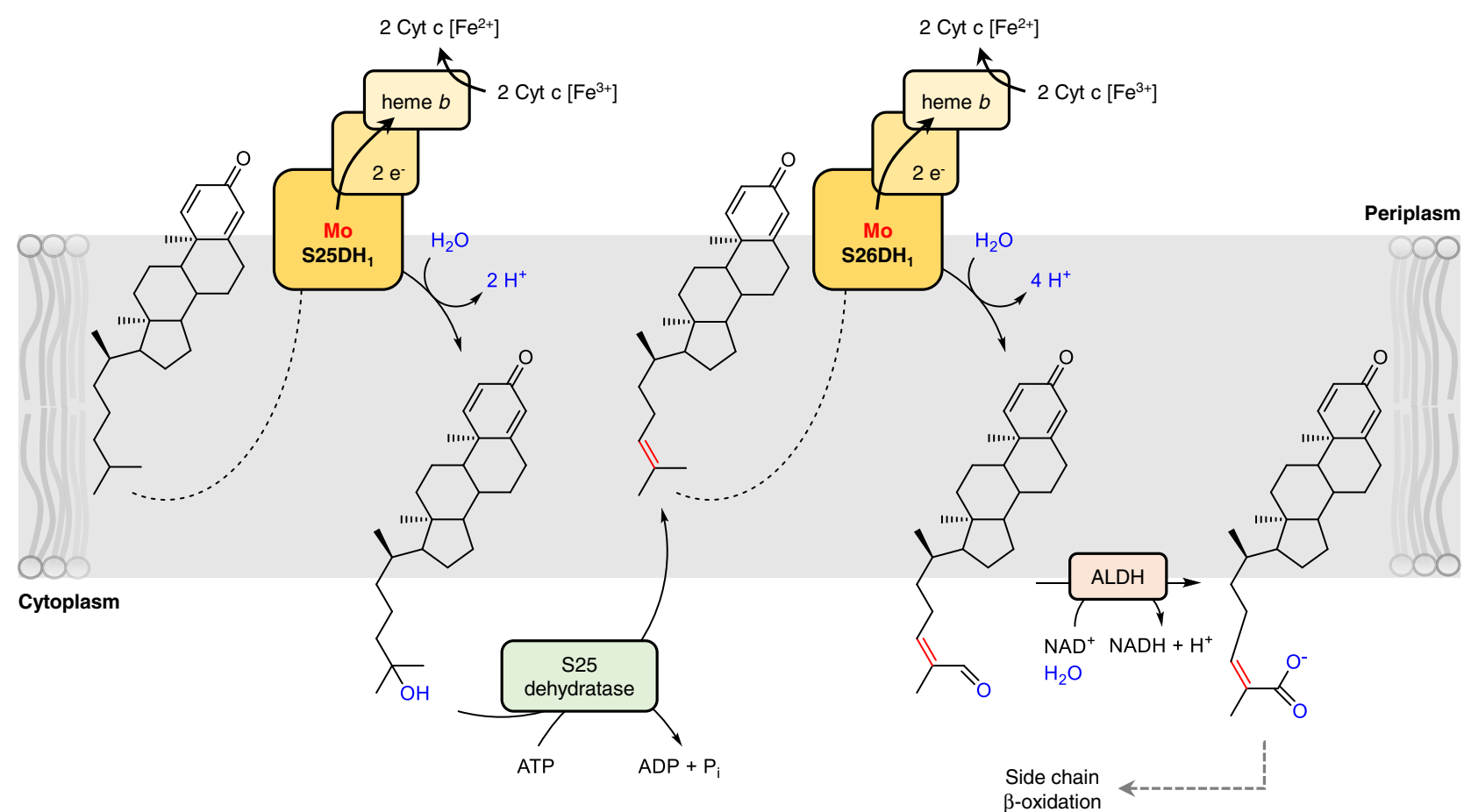

Fig. 5 Proposed subcellular localisation of initial anaerobic cholesterol degradation steps. For easier presentation, reduction of $\Delta 24$ double bond is omitted. The dotted arrows indicate that hydrophobic side chain needs to be bound by S25DH $\mathrm{DH}_{1}$ and $26 \mathrm{DH}_{1}$. The assignment of S25DH $\mathrm{H}_{1}$ and S26DH $\mathrm{St}_{1}$ the periplasm are based on their TAT sequence, that of S25 dehydratase and aldehyde dehydrogenase (ALDH) to the cytoplasm on their cytoplasmic cosubstrates. Hydroxylations at C25 and C26 abolish polarity of CDO/DDO and improves access from both sides of the cytoplasmic membrane.

$1.37-1.32(\mathrm{~m}, 4 \mathrm{H}), 1.30(\mathrm{~s}, 3 \mathrm{H}), 1.19-1.13(\mathrm{~m}, 2 \mathrm{H}), 1.10-1.01(\mathrm{~m}, 4 \mathrm{H}), 0.97(\mathrm{~d}$, $J=6.5 \mathrm{~Hz}, 3 \mathrm{H}), 0.82(\mathrm{~s}, 3 \mathrm{H}) .{ }^{13} \mathrm{C}$ NMR $\left(101 \mathrm{MHz}\right.$, methanol- $\left.d_{4}\right): \delta=188.8,173.9$, $159.7,127.5,123.9,81.0(\mathrm{~d}, J=7.3 \mathrm{~Hz}), 57.5,56.9,54.3,45.5,45.1(\mathrm{~d}, J=5.4 \mathrm{~Hz})$, $43.9,40.9,37.6,37.1,36.8,35.2,34.0,29.2,28.0(\mathrm{~d}, J=5.8 \mathrm{~Hz}), 28.0(\mathrm{~d}, J=5.9 \mathrm{~Hz})$, 25.4, 24.0, 21.8, 19.1, 12.5. ${ }^{31} \mathrm{P}\left\{{ }^{1} \mathrm{H}\right\}$ NMR $\left(162 \mathrm{MHz}\right.$, methanol- $\left.d_{4}\right): \delta=-3.03$. ESIHRMS $\left[\mathrm{M}-\mathrm{H}^{+}\right]^{-}$: calculated for $\mathrm{C}_{27} \mathrm{H}_{42} \mathrm{O}_{5} \mathrm{P} 477.2775$, found: 477.2772 .

Culture conditions and preparation of cell extracts. S. denitrificans was cultivated under denitrifying conditions in mineral medium with $2 \mathrm{mM}$ cholesterol and harvested anaerobically in the exponential phase $\left(8000 \times g, 20 \mathrm{~min}\right.$, and $\left.4{ }^{\circ} \mathrm{C}\right)$. T. aromatica $\mathrm{K} 172$ producing $\mathrm{S} 25 \mathrm{DH}_{1}$ and related enzymes was cultivated under denitrifying conditions using a phosphate-buffered medium with benzoate as carbon source at $30^{\circ} \mathrm{C}^{30}$. E. coli BL21 was cultivated under aerobic conditions in 2x YT medium ( $18 \mathrm{~g} \mathrm{~L}^{-1}$ tryptone, $10 \mathrm{~g} \mathrm{~L}^{-1}$ yeast extract and $\left.5 \mathrm{~g} \mathrm{~L}^{-1} \mathrm{NaCl}\right)$ medium at $37^{\circ} \mathrm{C}$. Cells were harvested anaerobically by centrifugation $(8000 \times g, 20 \mathrm{~min}$, and $4{ }^{\circ} \mathrm{C}$ ) in the late exponential phase. Frozen cells were lysed via a French pressure cell at $137 \mathrm{MPa}$, using 2 volumes of lysis buffer containing $50 \mathrm{mM}$ $\mathrm{MOPS} / \mathrm{KOH}$ (pH 7.0) and $0.1 \mathrm{mg}$ DNase I.

Enzyme assays. (1) Preliminary tests for the conversion of 25-OH-CDO with cellfree extracts $\left(0.4-0.6 \mathrm{mg} \mathrm{ml}^{-1}\right)$ of $S$. denitrificans were performed in $50 \mathrm{mM}$ MOPS/ KOH buffer (pH 7.0), $0.5 \mathrm{mM}$ 25-hydroxy-cholesta-1,4-dien-3-one (25-OH-CDO) or 25-hydroxy-cholest-4-en-3-one (25-OH-CEO), $2 \mathrm{mM}$ electron acceptor $\left(\mathrm{K}_{3}[\mathrm{Fe}\right.$ $(\mathrm{CN})_{6}$, phenazine methosulfate, 2,6-dichlorophenolindophenol, methylene blue, $\mathrm{NADP}^{+}$, or $\mathrm{NAD}^{+}$) or $2 \mathrm{mM}$ electron donor (titanium(III) citrate, sodium dithionite, benzyl viologen, methyl viologen, NADPH, or NADH) and 6\% (w/v) $\mathrm{HPCD}$ at $30^{\circ} \mathrm{C}$ under anoxic conditions.

(2) ATP-dependent dehydration of 25-OH-CDO to DDO was determined at $30{ }^{\circ} \mathrm{C}$ in the presence of $50 \mathrm{mM}$ Tris/ $\mathrm{HCl}$ buffer ( $\left.\mathrm{pH} 7.8\right), 0.2 \mathrm{mM} 25-\mathrm{OH}$-cholesta1,4-diene-3-one (10-25 mM concentrated in 2-propanol), $5 \mathrm{mM}$ ATP, $5 \mathrm{mM}$ $\mathrm{MgCl}_{2}$, and $6 \%(\mathrm{w} / \mathrm{v}) \mathrm{HPCD}$. For determination of kinetic parameters and stoichiometry of ATP hydrolysis, soluble proteins from S. denitrificans were subjected to $\left(\mathrm{NH}_{4}\right)_{2} \mathrm{SO}_{4}$ precipitation. At $40 \%$ saturation, the activity remained in the supernatant, whereas at $50 \%$ the enzyme was found in the precipitate. Enzyme assays were stopped by adding 5 volumes 2-propanol. After twofold-centrifugation, the supernatant was applied to an Acquity H-class UPLC system (Waters) for analysis. An Acquity UPLC CSH C18 $(1.7 \mu \mathrm{m}, 2.1 \times 100 \mathrm{~mm})$ column was used to separate the steroid compounds using $10 \mathrm{mM}$ aqueous $\mathrm{NH}_{4} \mathrm{OAc}$ and an increasing acetonitrile gradient. For the ATP/ADP stoichiometry measurements, the enzymatic assays were stopped using two $(\mathrm{v} / \mathrm{v})$ volumes ethyl acetate. The organic solvent was diluted in $5(\mathrm{v} / \mathrm{v})$ volumes 2-propanol and centrifuged twice $(8,000 \times g)$ and loaded onto an Acquity H-class UPLC system. The aqueous phase $(20 \mu \mathrm{L})$ was acidified using $5 \mu \mathrm{L} 0.25 \mathrm{M} \mathrm{HCl}$ and centrifuged twice for $20 \mathrm{~min}$ at $4{ }^{\circ} \mathrm{C}$. The supernatant was neutralised using $20(\mathrm{v} / \mathrm{v})$ volumes MOPS/KOH buffer $(\mathrm{pH} 7.0)$ To determine the ATP consumption, an Acquity UPLC HSS T3 $(1.8 \mu \mathrm{M}, 2.1 \times$ $100 \mathrm{~mm}$ ) column was used isocratically with a $10 \mathrm{mM}$ potassium phosphate buffer $(\mathrm{pH} 6.5)^{44}$

(3) Conversion of DDO to 26-OH-DDO and DDO-26-al was performed in cellfree extracts $\left(0.4-0.6 \mathrm{mg} \mathrm{mL}^{-1}\right)$ of $S$. denitrificans or enriched S26DH $(0.05-0.1 \mathrm{mg}$ $\mathrm{mL}^{-1}$ ) using $50 \mathrm{mM} \mathrm{MOPS/KOH}$ buffer (pH 7.0) in the presence of $0.2 \mathrm{mM}$ DDO (added from $10-25 \mathrm{mM}$ stock in 2-propanol), $5 \mathrm{mM} \mathrm{K}_{3}\left[\mathrm{Fe}(\mathrm{CN})_{6}\right.$ ], and $6 \%(\mathrm{w} / \mathrm{v})$ HPCD at $30^{\circ} \mathrm{C}$ under shaking $(300 \mathrm{rpm})$ in an anaerobic glove box $\left(\mathrm{O}_{2}\right.$ levels $<$ $2 \mathrm{ppm})$. Assays were stopped as described above.

(4) Conversion of DDO-26-al to DDO-26-carboxylate was carried out in $50 \mathrm{mM}$ MOPS/KOH buffer (pH 7.0) using 0.2 mM DDO-26-al (10-25 mM stock in 2-propanol), $5 \mathrm{mM} \mathrm{NAD}^{+}$, and $6 \%(\mathrm{w} / \mathrm{v}) \mathrm{HPCD}$ using cell-free extract $\left(0.4-0.6 \mathrm{mg} \mathrm{mL}^{-1}\right)$ of $S$. denitrificans or cell-free extracts $\left(1.5 \mathrm{mg} \mathrm{mL}^{-1}\right)$ of $E$. coli BL21 producing $\mathrm{C} 26-\mathrm{ALDH}$ at $30^{\circ} \mathrm{C}$ under shaking $(300 \mathrm{rpm})$. Assays were stopped as described above.

Heterologous production of S26DHs in T. aromatica K172. Gene clusters encoding the $\alpha_{5} \beta_{5} \gamma_{5}-\left(\mathrm{DH}_{5}\right), \alpha_{6} \beta_{6} \gamma_{6}-\left(\mathrm{DH}_{6}\right), \alpha_{7} \beta_{7} \gamma_{7}-\left(\mathrm{DH}_{7}\right)$ subunits were amplified using primers suitable for T4 ligation (Supplementary Table S4). The resulting 4.7-kb DNA fragments were HindIII/SpeI double digested; the gene encoding SdhD $\left(\delta_{4}\right)$ was amplified using SdhD_for and SdhD_rev primers (Supplementary Table S4), generating a 0.9-kb DNA fragment that was SpeI/XbaI double digested. All fragments were cloned into the broad-host-range vector pIZ1016 $\left(\mathrm{Gm}^{\mathrm{r}}\right.$, oripBBR1, $\mathrm{Mob}^{+}$, lacZa, PtacllacI $\left.\mathrm{I}\right)$, and transformed $(1.7 \mathrm{kV}, 5 \mathrm{~ms})$ into $T$. aromatica. For gene expression, cells were cultivated under denitrifying conditions $\left(30^{\circ} \mathrm{C}\right)$ in phosphate-buffered medium with benzoate, supplemented with $20 \mu \mathrm{g} \mathrm{mL}^{-1}$ gentamycin and $1 \mathrm{mM} \mathrm{IPTG}^{30}$.

Heterologous production of AcmB in E. coli BL21. The gene encoding AcmB was amplified using the primers listed in Supplementary Table S4. The resulting $1.8-\mathrm{kb}$ DNA fragment was SacI/HindIII double digested and cloned into pASK-IBA15plus before transformed into E. coli BL21. Induction of AcmB was carried out in 2 YT medium at $20^{\circ} \mathrm{C}$, supplemented with $100 \mu \mathrm{g} \mathrm{mL}{ }^{-1}$ ampicillin and $20 \mu \mathrm{g} \mathrm{mL}-1$ anhydrotetracycline. Cells were harvested in the late exponential phase (16 hours induction) and used for further experiments. 
Heterologous production of DDO-26-al dehydrogenase (C26-ALDH) in E. coli BL21. The C26-ALDH gene (WP_154716401) was amplified using the primers listed in Supplementary Table S4. The resulting $1.5-\mathrm{kb}$ DNA Fragment was digested by NheI/NcoI and cloned into pASK-IBA15plus and transformed into E. coli BL21. Induction of C26-ALDH was carried out as described for the AcmB gene.

Enrichment of S26DH ${ }_{1}$ after heterologous production in T. aromatica K172. All steps were performed under anaerobic conditions in an anaerobic glove box $(95 \%$ $\mathrm{N}_{2}, 5 \% \mathrm{H}_{2}$, by vol.; $\mathrm{O}_{2}<2 \mathrm{ppm}$ ). The buffers and reagents used were degassed using alternating $(20$ cycles $) \mathrm{N}_{2}(0.5 \mathrm{bar})$ and vacuum $(>-0.9$ bar) to reach anaerobicity. Anaerobically harvested cells were lysed with a French pressure cell at $137 \mathrm{MPa}$ using two volumes (w/v) of buffer A ( $20 \mathrm{mM} \mathrm{Tris} / \mathrm{HCl} \mathrm{pH} \mathrm{7.0,0.02 \%} \mathrm{[w/v]} \mathrm{Tween}$ $20,0.5 \mathrm{mM}$ dithioertythritol [DTE]). Solubilisation of lyzed cells was carried out for $16 \mathrm{~h}$ at $4{ }^{\circ} \mathrm{C}$ using $1 \%(\mathrm{v} / \mathrm{v})$ Tween 20 . After ultra-centrifugation at $150,000 \times \mathrm{g}$ for $1.5 \mathrm{~h}$, the supernatant was used for enzyme enrichment. The soluble proteins were applied to a DEAE-Sepharose column (75 mL; GE Healthcare) at $7.5 \mathrm{~mL} \mathrm{~min}^{-1}$ and washed with buffer $\mathrm{A}$. The active protein fraction was eluted by increasing the amount of buffer B (20 mM TRIS/HCl pH 7.0, $0.5 \mathrm{mM} \mathrm{DTE}, 0.02 \%[\mathrm{w} / \mathrm{v}]$ Tween $20,500 \mathrm{mM} \mathrm{KCl}$ ) from $50 \mathrm{mM}$ to $150 \mathrm{mM} \mathrm{KCl}$. Active fractions were concentrated (30-kDa cut-off membrane), diluted in 10 volumes of buffer C (20 mM TRIS/MES $\mathrm{pH}$ 6.0, $0.5 \mathrm{mM}$ DTE, $0.01 \%$ [w/v] Tween 20), and applied to a Reactive Red 120 column $\left(40 \mathrm{~mL}\right.$; GE Healthcare) at $5 \mathrm{~mL} \mathrm{~min}{ }^{-1}$. Elution of active fraction was carried out by increasing the gradient of buffer D $(20 \mathrm{mM}$ TRIS/HCl pH 8.0, $0.5 \mathrm{mM}$ DTE, $0.01 \%[\mathrm{w} / \mathrm{v}$ ] Tween 20$)$ from $\mathrm{pH} 7$ to $\mathrm{pH}$ 8. The active protein fraction was concentrated (30-kDa cut-off membrane), and applied to a Superdex 200 column $(320 \mathrm{~mL})$ at $2 \mathrm{~mL} \mathrm{~min}^{-1}$ that was equilibrated with buffer E $(20 \mathrm{mM}$ Tris/ $\mathrm{HCl} \mathrm{pH} \mathrm{7.5,} 150 \mathrm{mM} \mathrm{KCl}$. The protein eluted in a single peak and was used for further experiments. Uncropped and unprocessed SDS-polyacrylamide gels of enriched enzyme are available in the accompanying Source Data File.

Spectrophotometric determination of $\mathbf{M o}, \mathbf{F e}$ and heme $\mathbf{b}$. Iron was determined with o-phenantroline using a modified protocol as described ${ }^{45}$. Enriched proteins $(5 \mu \mathrm{L})$ were added to $245 \mu \mathrm{L} \mathrm{H} \mathrm{H}_{2} \mathrm{O}$ and acidified with $7.5 \mu \mathrm{L} 25 \% \mathrm{HCl}$, mixed, incubated at $80^{\circ} \mathrm{C}$ for $10 \mathrm{~min}$, followed by centrifugation at $10,000 \times g$ for $10 \mathrm{~min}$. The supernatant was transferred and $750 \mu \mathrm{L} \mathrm{H}_{2} \mathrm{O}, 50 \mu \mathrm{L} 10 \%$ [w/v] hydroxylamine and $0.1 \%[\mathrm{w} / \mathrm{v}]$ o-phenanthroline were added, mixed and incubated at room temperature for $30 \mathrm{~min}$. The absorbance was measured at $512 \mathrm{~nm}$ and compared with a $\left(\mathrm{NH}_{4}\right)_{2} \mathrm{Fe}\left(\mathrm{SO}_{4}\right)_{2}$ standard.

Mo was determined colorimetrically with dithiol using a modified protocol ${ }^{46}$. $20 \mu \mathrm{L}$ proteins were incubated at $60^{\circ} \mathrm{C}$ until dryness was reached. The dried product was solved in $250 \mu \mathrm{L} 4 \mathrm{M} \mathrm{HCl}$ and heated to $90^{\circ} \mathrm{C}$ for $30 \mathrm{~min} .100 \mu \mathrm{L}$ reducing solution $\left(15 \%[\mathrm{w} / \mathrm{v}]\right.$ ascorbic acid and $2 \%[\mathrm{w} / \mathrm{v}]$ citric acid in $\left.\mathrm{H}_{2} \mathrm{O}\right)$ were added, mixed and incubated for $5 \mathrm{~min}$ at room temperature. $300 \mu \mathrm{L} \mathrm{H}_{2} \mathrm{O}$ and $100 \mu \mathrm{L}$ dithiol solution $(0.1 \mathrm{~g}$ zinc dithiol and $0.4 \mathrm{~g} \mathrm{NaOH}$ diluted in $600 \mu \mathrm{L}$ ethanol, $31 \mathrm{~mL} \mathrm{H}_{2} \mathrm{O}$ and $200 \mu \mathrm{L}$ thioglycollic acid) were added, mixed and incubated for $5 \mathrm{~min}$. Then, $500 \mu \mathrm{L}$ isoamyl acetate were added and the mixture was shaken vigorously for $1 \mathrm{~min}$. The absorbance was measured in the organic phase at $680 \mathrm{~nm}$ and compared with a sodium molybdate dihydrate standard.

The heme $b$ content was determined spectrophotometrically at $556 \mathrm{~nm}$ after the anaerobically conducted complete reduction of the enzyme with sodium dithionite. The heme-content was calculated using the extinction coefficient of reduced heme $b\left(\varepsilon_{556}=34.64 \mathrm{mM}^{-1} \mathrm{~cm}^{-1}\right)^{47}$.

Protein identification by mass spectrometry of peptides. Proteins were identified by excising the bands of interest from SDS-PAGE gels. After in-gel digestion with trypsin, the resulting peptides were separated by UPLC and identified using a Synapt G2-Si high-resolution mass spectrometry (HRMS) electrospray ionisation quadrupole time-of-flight (ESI-Q-TOF) mass spectrometry system (Waters); the system has been described in detail previously ${ }^{48}$.

LC-ESI-MS analyses of steroid compounds. Metabolites were analysed by an Acquity I-class UPLC system (Waters) using an Acquity UPLC CSH C18 $(1.7 \mu \mathrm{m}$, $2.1 \times 100 \mathrm{~mm}$ ) column coupled to a Synapt G2-Si HRMS ESI-Q-TOF device (Waters). For separation, an aqueous $10 \mathrm{mM} \mathrm{NH}_{4} \mathrm{OAc}$ /acetonitrile gradient was applied. Samples were measured in positive mode with a capillary voltage of $2 \mathrm{kV}$, $100^{\circ} \mathrm{C}$ source temperature, $450^{\circ} \mathrm{C}$ desolvation temperature, $1000 \mathrm{~L} \mathrm{~min}^{-1} \mathrm{~N}_{2}$ desolvation gas flow, and $30 \mathrm{~L} \mathrm{~min}^{-1} \mathrm{~N}_{2}$ cone gas flow. Evaluation of LC-MS metabolites was performed using MassLynx (Waters). Metabolites were identified by their retention times, UV-vis spectra, $\mathrm{m} / \mathrm{z}$ values.

NMR analyses of steroid compounds. Deuterated solvents for NMR and reactions were obtained from Armar Chemicals, Switzerland and eurisotop, Germany. NMR spectra were measured on a Bruker Avance Neo $400 \mathrm{MHz}$ or on a Bruker DRX $400 \mathrm{MHz}$ spectrometer. Internal solvent peaks $\left({ }^{1} \mathrm{H}\right.$ NMR: methanol- $d_{3}$ : $3.31 \mathrm{ppm} ; \mathrm{CHCl}_{3}: 7.26 \mathrm{ppm} ;{ }^{13} \mathrm{C}$ NMR: methanol- $d_{4}: 49.0 \mathrm{ppm} ; \mathrm{CDCl}_{3}: 77.0 \mathrm{ppm}$ ) were used as a reference. Data are reported as follows: chemical shift $(\delta, \mathrm{ppm})$, multiplicity (s, singlet; d, doublet; t, triplet; q, quartet; m, multiplet; br. s, broad signal), coupling constant(s) $(\mathrm{J}, \mathrm{Hz})$, integration. For ${ }^{31} \mathrm{P}$ NMR spectra all signals were referenced to an internal standard (PPP).

The chemical structure of cholesta-1,4,24-trien-3-one (DDO, 3) was deduced from ${ }^{1} \mathrm{H},{ }^{13} \mathrm{C}$, and $2 \mathrm{D}$ NMR experiments (see Supplementary Fig. S1). In addition to the A-ring signals ( ${ }^{13} \mathrm{C}$ NMR signals at 156.0 (C1), 127.4 (C2), 186.4 (C3), 123.7 (C4), 169.4 (C5) ppm; ${ }^{1} \mathrm{H}$ NMR signals at $6.98 \mathrm{ppm}, 1 \mathrm{H}, \mathrm{d}, J=10.1 \mathrm{~Hz}, \mathrm{H1} ; 6.15$ ppm, $1 \mathrm{H}, \mathrm{dd}, J=10.1,1.9 \mathrm{~Hz}, \mathrm{H} 2 ; 5.99 \mathrm{ppm}, 1 \mathrm{H}$, ' $\mathrm{t}$ ', $J=1.6 \mathrm{~Hz}, \mathrm{H} 4$ ), the compound was characterised through ${ }^{13} \mathrm{C}$ NMR signals at $125.0 \mathrm{ppm}$ (C24, HSQC cross peak to ${ }^{1} \mathrm{H}$ NMR $\delta=5.01 \mathrm{ppm}, 1 \mathrm{H}$, tsept, $J=7.1,1.3 \mathrm{~Hz}$ ) and $131.0 \mathrm{ppm}$ (C25). The corresponding ${ }^{1} \mathrm{H}$ NMR signals were identified through HSQC and HMBC pulse experiments. ${ }^{13} \mathrm{C}$ NMR $\left(100 \mathrm{MHz}, \mathrm{CDCl}_{3}\right): \delta=186.4,169.4,156.0$, 131.0, 127.4, 125.0, 123.7, 55.9, 55.4, 52.3, 43.6, 42.6, 39.4, 35.9, 35.5 (2 C), 33.6, $32.9,28.0,25.7,24.6,24.3,22.8,18.6,18.4,17.6,12.0 \mathrm{ppm}$.

The chemical structure of 26-hydroxycholesta-1,4,24-trien-3-one (26-OH-DDO, 4) was deduced from ${ }^{1} \mathrm{H},{ }^{13} \mathrm{C}$, and $2 \mathrm{D}$ NMR experiments (see Supplementary Fig. 5) In addition to the A-ring signals $\left({ }^{13} \mathrm{C}\right.$ NMR signals at $156.0(\mathrm{C} 1), 127.4(\mathrm{C} 2), 186.4$ (C3), 123.7 (C4), 169.5 (C5) ppm; ${ }^{1} \mathrm{H}$ NMR $\delta=7.06 \mathrm{ppm}, 1 \mathrm{H}, \mathrm{d}, J=10.1 \mathrm{~Hz}, \mathrm{H1}$; $6.22 \mathrm{ppm}, 1 \mathrm{H}, \mathrm{dd}, J=10.1,1.9 \mathrm{~Hz}, \mathrm{H} 2 ; 6.07 \mathrm{ppm}, 1 \mathrm{H}$, 't', $J=1.6 \mathrm{~Hz}, \mathrm{H} 4)$, the compound was characterised through ${ }^{13} \mathrm{C}$ NMR signals at $126.8 \mathrm{ppm}$ (C24, HSQC cross peak to ${ }^{1} \mathrm{H}$ NMR $\left.\delta=5.38 \mathrm{ppm}, 1 \mathrm{H}, \mathrm{t}, \mathrm{br}, J=7.2 \mathrm{~Hz}\right)$ and $134.3 \mathrm{ppm}(\mathrm{C} 25)$, as well as ${ }^{13} \mathrm{C}$ NMR signals at $69.0 \mathrm{ppm}\left(\mathrm{CH}_{2} \mathrm{OH}, \mathrm{C} 26\right.$, $\mathrm{HSQC}$ cross peak to ${ }^{1} \mathrm{H}$ NMR $\delta=4.00 \mathrm{ppm}, 2 \mathrm{H}, \mathrm{s})$ and $13.6 \mathrm{ppm}\left(\mathrm{CH}_{3}, \mathrm{C} 27\right.$, HSQC cross peak to ${ }^{1} \mathrm{H}$ NMR $\delta=$ $1.66 \mathrm{ppm}, 3 \mathrm{H}, \mathrm{s})$. The corresponding ${ }^{1} \mathrm{H}$ NMR signals and the $E$-configuration of the C24,C25 double bond were identified through HSQC, HMBC, and 1D NOESY pulse experiments (see Supplementary Fig. 5). ${ }^{13} \mathrm{C}$ NMR $\left(100 \mathrm{MHz}, \mathrm{CDCl}_{3}\right): \delta=186.4$, $169.5,156.0,134.3,127.4,126.8,123.7,69.0,55.9,55.4,52.3,43.6,42.6,39.4,35.53$, $35.49,35,45,33.6,32.9,28.1,24.3,24.2,22.8,18.6,18.4,13.6,12.0$ ppm.

The chemical structure of 26-oxocholesta-1,4,24-trien-3-one (DDO-26-al, 5) was deduced from ${ }^{1} \mathrm{H},{ }^{13} \mathrm{C}$, and 2D NMR experiments (see Supplementary Fig. 6). In addition to the A-ring signals $\left({ }^{13} \mathrm{C}\right.$ NMR signals at 156.0 (C1), 127.4 (C2), 186.4 (C3), 123.7 (C4), 169.4 (C5) ppm; ${ }^{1} \mathrm{H}$ NMR $\delta=7.05 \mathrm{ppm}, 1 \mathrm{H}, \mathrm{d}, J=10.2 \mathrm{~Hz}, \mathrm{H} 1$; $6.23 \mathrm{ppm}, 1 \mathrm{H}$, dd, $J=10.2,1.9 \mathrm{~Hz}, \mathrm{H} 2 ; 6.07 \mathrm{ppm}, 1 \mathrm{H}$, ' $\mathrm{t}$ ', $J=1.5 \mathrm{~Hz}, \mathrm{H} 4)$, the compound was characterised through ${ }^{13} \mathrm{C}$ NMR signals at $155.3 \mathrm{ppm}$ (C24, HSQC cross peak to ${ }^{1} \mathrm{H}$ NMR $\left.\delta=6.47 \mathrm{ppm}, 1 \mathrm{H}, \mathrm{t}, \mathrm{br}, J=7.0 \mathrm{~Hz}\right)$ and $139.1 \mathrm{ppm}(\mathrm{C} 25)$, as well as ${ }^{13} \mathrm{C}$ NMR signals at $195.4 \mathrm{ppm}\left(\mathrm{CHO}, \mathrm{C} 26, \mathrm{HSQC}\right.$ cross peak to ${ }^{1} \mathrm{H}$ NMR $\delta=9.39 \mathrm{ppm}, 1 \mathrm{H}, \mathrm{s})$ and $9.1 \mathrm{ppm}\left(\mathrm{CH}_{3}, \mathrm{C} 27\right.$, HSQC cross peak to ${ }^{1} \mathrm{H}$ NMR $\delta=$ $1.75 \mathrm{ppm}, 3 \mathrm{H}, \mathrm{s})$. The corresponding ${ }^{1} \mathrm{H}$ NMR signals and the $E$-configuration of the C24,C25 double bond were identified through HSQC, HMBC, and 1D NOESY pulse experiments (see Supplementary Fig. 6). ${ }^{13} \mathrm{C}$ NMR $\left(100 \mathrm{MHz}, \mathrm{CDCl}_{3}\right): \delta=195.4$, 186.4, 169.4, 156.0, 155.3, 139.1, 127.4, 123.7, 55.7, 55.4, 52.3, 43.6, 42.7, 39.4, 35.5, $35.4,34.3,33.6,32.8,28.1,25.7,24.3,22.8,18.6,18.3,12.0,9.1 \mathrm{ppm}$.

Reporting summary. Further information on research design is available in the Nature Research Reporting Summary linked to this article.

\section{Data availability}

The source data underlying Figs. 2a, b, 3a, 4a, 4b, Supplementary Tables 1 and 2, Supplementary Figs. 4a-d, 7, 8, and 9a, b are provided in the Source Data file. Additional data that support the findings of this study are available from the corresponding author upon reasonable request. Source data are provided with this paper.

Received: 6 March 2020; Accepted: 9 July 2020; Published online: 06 August 2020

\section{References}

1. Dong, J. J. et al. Biocatalytic oxidation reactions: a chemist's perspective. Angew. Chem. Int. Ed. 57, 9238-9261 (2018).

2. Yamaguchi, J., Yamaguchi, A. D. \& Itami, K. C-H bond functionalization: emerging synthetic tools for natural products and pharmaceuticals. Angew. Chem. Int. Ed. 51, 8960-9009 (2012).

3. Roduner, E. et al. Selective catalytic oxidation of $\mathrm{C}-\mathrm{H}$ bonds with molecular oxygen. ChemCatChem 5, 82-112 (2013).

4. Engelmann, X., Monte-Pérez, I. \& Ray, K. Oxidation reactions with bioinspired mononuclear non-heme metal-oxo complexes. Angew. Chem. Int. Ed. 55, 7632-7649 (2016).

5. White, C. M. \& Zhao, J. Aliphatic C-H oxidations for late-stage functionalization. J. Am. Chem. Soc. 140, 13988-14009 (2018).

6. Hofrichter, M. \& Ullrich, R. Oxidations catalysed by fungal peroxygenases. Curr. Opin. Chem. Biol. 19, 116-125 (2014).

7. Hrycay, E. G. \& Bandiera, S. M. Monooxygenase, peroxidase and peroxygenase properties and reaction mechanisms of cytochrome P450 enzymes. Adv. Exp. Med. Biol. 851, 1-61 (2015). 
8. Wang, Y., Lan, D., Durrani, R. \& Hollmann, F. Peroxygenases en route to becoming dream catalysts. What are the opportunities and challenges? Curr. Opin. Chem. Biol. 37, 1-9 (2017).

9. Ortiz de Montellano, P. R. Hydrocarbon hydroxylation by cytochrome p450 enzymes. Chem. Rev. 110, 932-948 (2010).

10. Rabus, R. et al. Anaerobic microbial degradation of hydrocarbons: from enzymatic reactions to the environment. J. Mol. Microbiol. Biotechnol. 26 5-28 (2016).

11. Efimov, I. \& McIntire, W. S. Relationship between charge-transfer interactions, redox potentials, and catalysis for different forms of the flavoprotein component of p-cresol methylhydroxylase. J. Am. Chem. Soc. 127, 732-741 (2005).

12. Johannes, J., Bluschke, A., Jehmlich, N., Von Bergen, M. \& Boll, M. Purification and characterization of active-site components of the putative $p$ cresol methylhydroxylase membrane complex from Geobacter metallireducens. J. Bacteriol. 190, 6493-6500 (2008).

13. Strijkstra, A. et al. Anaerobic activation of $p$-cymene in denitrifying betaproteobacteria: methyl group hydroxylation versus addition to fumarate. Appl. Environ. Microbiol. 80, 7592-7603 (2014).

14. Heider, J., Szaleniec, M., Sünwoldt, K. \& Boll, M. Ethylbenzene dehydrogenase and related molybdenum enzymes involved in oxygen-independent alkyl chain hydroxylation. J. Mol. Microbiol. Biotechnol. 26, 45-62 (2016).

15. Kniemeyer, O. \& Heider, J. Ethylbenzene dehydrogenase, a novel hydrocarbon-oxidizing molybdenum/iron-sulfur/heme enzyme. J. Biol. Chem. 276, 21381-21386 (2001).

16. Puentes-Cala, E., Liebeke, M., Markert, S. \& Harder, J. Limonene dehydrogenase hydroxylates the allylic methyl group of cyclic monoterpenes in the anaerobic terpene degradation by Castellaniella defragrans. J. Biol. Chem. 293, 9520-9529 (2018).

17. Ting, Y. F. \& Praveena, S. M. Sources, mechanisms, and fate of steroid estrogens in wastewater treatment plants: a mini review. Environ. Monit. Assess. 189, 178 (2017).

18. Vilela, C. L. S., Bassin, J. P. \& Peixoto, R. S. Water contamination by endocrine disruptors: Impacts, microbiological aspects and trends for environmental protection. Environ. Pollut. 235, 546-559 (2018).

19. Holert, J. et al. Metagenomes reveal global distribution of bacterial steroid catabolism in natural, engineered, and host environments. MBio 9, e02345-17 (2018).

20. Driscoll, M. D. et al. Structural and biochemical characterization of Mycobacterium tuberculosis CYP142: evidence for multiple cholesterol 27 hydroxylase activities in a human pathogen. J. Biol. Chem. 285, 38270-38282 (2010).

21. Van Der Geize, R. et al. A gene cluster encoding cholesterol catabolism in a soil actinomycete provides insight into Mycobacterium tuberculosis survival in macrophages. Proc. Natl. Acad. Sci. USA 104, 1947-1952 (2007).

22. García, J. L., Uhía, I. \& Galán, B. Catabolism and biotechnological applications of cholesterol degrading bacteria. Microb. Biotechnol. 5, 679-699 (2012).

23. Yam, K. C., Okamoto, S., Roberts, J. N. \& Eltis, L. D. Adventures in Rhodococcus - from steroids to explosives. Can. J. Microbiol 57, 155-168 (2011).

24. Wang, P.-H. et al. An oxygenase-independent cholesterol catabolic pathway operates under oxic conditions. PLoS ONE 8, e66675 (2013).

25. Warnke, M. et al. A patchwork pathway for oxygenase-independent degradation of side chain containing steroids. Environ. Microbiol. 19, 4684-4699 (2017).

26. Warnke, M. et al. Functional characterization of three specific acyl-coenzyme A synthetases involved in anaerobic cholesterol degradation in Sterolibacterium denitrificans Chol1S. Appl. Environ. Microbiol. 84, e02721-17 (2018).

27. Chiang, Y.-R. et al. Study of anoxic and oxic cholesterol metabolism by Sterolibacterium denitrificans. J. Bacteriol. 190, 905-914 (2008).

28. Chiang, Y.-R., Ismail, W., Müller, M. \& Fuchs, G. Initial steps in the anoxic metabolism of cholesterol by the denitrifying Sterolibacterium denitrificans. J. Biol. Chem. 282, 13240-13249 (2007).

29. Dermer, J. \& Fuchs, G. Molybdoenzyme that catalyzes the anaerobic hydroxylation of a tertiary carbon atom in the side chain of cholesterol. J. Biol. Chem. 287, 36905-36916 (2012).

30. Jacoby, C. et al. Four molybdenum-dependent steroid C-25 hydroxylases: Heterologous overproduction, role in steroid degradation, and application for 25-hydroxyvitamin $\mathrm{D}_{3}$ synthesis. MBio 9, e00694-18 (2018).

31. Warnke, M. et al. 25-Hydroxyvitamin D3 synthesis by enzymatic steroid sidechain hydroxylation with Water. Angew. Chem. Int. Ed. 55, 1881-1884 (2016).

32. Lin, C.-W. et al. Substrate uptake and subcellular compartmentation of anoxic cholesterol catabolism in Sterolibacterium denitrificans. J. Biol. Chem. 290, 1155-1169 (2015).

33. Cremosnik, G. S., Hofer, A. \& Jessen, H. Iterative synthesis of nucleoside oligophosphates with phospramidites. Angew. Chem. Int. Ed. 53, 286-289 (2014).
34. Kuntze, K. et al. 6-Oxocyclohex-1-ene-1-carbonyl-coenzyme A hydrolases from obligately anaerobic bacteria: characterization and identification of its gene as a functional marker for aromatic compounds degrading anaerobes. Environ. Microbiol. 10, 1547-1556 (2008).

35. Lossing, F. F. \& Holmes, J. L. Stabilization energy and ion size in carbocations in the gas phase. J. Am. Chem. Soc. 106, 6917-6920 (1984).

36. Dhe-Paganon, S., Magrath, J. \& Abeles, R. H. Mechanism of mevalonate pyrophosphate decarboxylase: evidence for a carbocationic transition state. Biochemistry 33, 13355-13362 (1994).

37. Vinokur, J. M. et al. Structural analysis of mevalonate-3-kinase provides insight into the mechanisms of isoprenoid pathway decarboxylases. Protein Sci. 24, 212-220 (2015).

38. Acheson, S. A., Kirkman, H. N. \& Wolfenden, R. Equilibrium of 5,6-hydration of NADH and mechanism of ATP-dependent dehydration. Biochemistry 27, 7371-7375 (1988)

39. Hyman, M. Biodegradation of gasoline ether oxygenates. Curr. Opin. Biotechnol. 24, 443-450 (2013).

40. Häggblom, M. M., Youngster, L. K. G., Somsamak, P. \& Richnow, H. H. Anaerobic biodegradation of methyl tert-butyl ether (MTBE) and related fuel oxygenates. Adv. Appl. Microbiol. 62, 1-20 (2007).

41. Choubey, A., Kalia, R. K., Malmstadt, N., Nakano, A. \& Vashishta, P. Cholesterol translocation in a phospholipid membrane. Biophys. J. 104, 2429-2436 (2013).

42. Bennett, W. F. D., MacCallum, J. L., Hinner, M. J., Marrink, S. J. \& Tieleman, D. P. Molecular view of cholesterol flip-flop and chemical potential in different membrane environments. J. Am. Chem. Soc. 131, 12714-12720 (2009).

43. Parisio, G., Sperotto, M. M. \& Ferrarini, A. Flip-flop of steroids in phospholipid bilayers: effects of the chemical structure on transbilayer diffusion. J. Am. Chem. Soc. 134, 12198-12208 (2012).

44. Tiedt, O., Fuchs, J., Eisenreich, W. \& Boll, M. A catalytically versatile benzoylCoA reductase, key enzyme in the degradation of methyl- and halobenzoates in denitrifying bacteria. J. Biol. Chem. 293, 10264-10274 (2018).

45. Fortune, W. B. \& Mellon, M. G. Determination of iron with o-phenanthroline a spectrophotometric study. Ind. Eng. Chem. Anal. Ed. 10, 60-64 (1938).

46. Quinn, B. F. \& Brooks, R. R. The rapid colorimetric determination of molybdenum with dithiol in biological, geochemical and steel samples. Anal. Chim. Acta 74, 75-84 (1975).

47. Berry, E. A. \& Trumpower, B. L. Simultaneous determination of hemes $\mathrm{a}, \mathrm{b}$, and c from pyridine hemochrome spectra. Anal. Biochem. 161, 1-15 (1987).

48. Mergelsberg, M., Egle, V. \& Boll, M. Evolution of a xenobiotic degradation pathway: formation and capture of the labile phthaloyl-CoA intermediate during anaerobic phthalate degradation. Mol. Microbiol. 108, 614-626 (2018).

\section{Acknowledgements}

This work was funded by the German Research Foundation (DFG), RTG 1976, project number 235777276. We thank Georg Fuchs, Freiburg, for continuous scientific advice.

\section{Author contributions}

C.J. performed all enzyme assays, carried UPLC and MS analyses, analysed data, heterologously produced and characterised enzymes, prepared figures and contributed to the writing of the manuscript; S.F. conducted NMR analyses, D.B. and H.J. chemically synthesised and analysed a 25-phospho-desmost-1,4-diene-3-one standard, and contributed to the writing of the paper; M.M. analysed NMR data and contributed to the design of the study; M.B., designed the study, analysed data and wrote the paper. All authors discussed the results and commented on the manuscript.

\section{Competing interests}

The authors declare no competing interests.

\section{Additional information}

Supplementary information is available for this paper at https://doi.org/10.1038/s41467 020-17675-7.

Correspondence and requests for materials should be addressed to M.B.

Peer review information Nature Communications thanks Wuyuan Zhang and the other, anonymous reviewer(s) for their contribution to the peer review of this work. Peer review reports are available.

Reprints and permission information is available at http://www.nature.com/reprints

Publisher's note Springer Nature remains neutral with regard to jurisdictional claims in published maps and institutional affiliations. 
(c) (i) Open Access This article is licensed under a Creative Commons Attribution 4.0 International License, which permits use, sharing, adaptation, distribution and reproduction in any medium or format, as long as you give appropriate credit to the original author(s) and the source, provide a link to the Creative Commons license, and indicate if changes were made. The images or other third party material in this article are included in the article's Creative Commons license, unless indicated otherwise in a credit line to the material. If material is not included in the article's Creative Commons license and your intended use is not permitted by statutory regulation or exceeds the permitted use, you will need to obtain permission directly from the copyright holder. To view a copy of this license, visit http://creativecommons.org/ licenses/by/4.0/.

(C) The Author(s) 2020 